\title{
An assessment of the performance of a biogas digester when insulated with sawdust
}

\author{
Patrick Mukumba*, Golden Makaka, Chipo Shonhiwa \\ Physics Department, University of Fort Hare, P. Bag X1314, King Williams Road, Alice, 5700, South Africa
}

Email address:

pmukumba@ufh.ac.za (P. Mukumba)

\section{To cite this article:}

Patrick Mukumba, Golden Makaka, Chipo Shonhiwa. An Assessment of the Performance of a Biogas Digester When Insulated with Sawdust. International Journal of Energy and Power Engineering. Vol. 4, No. 2, 2015, pp. 24-31. doi: 10.11648/j.ijepe.20150402.12

\begin{abstract}
Biogas is mixture of gases, predominantly methane and carbon dioxide, produced by anaerobic digestion. In biogas production temperature of slurry is an important parameter that affects the rate of biogas production. The biogas digester was fed with cow dung before it was insulated. Ambient, biogas and slurry temperatures were measured. The temperature sensors were connected to the CR1000 data logger. Results were collected and compared before the construction of the second wall of the digester for the insulation. There was a strong positive relationship between slurry and ambient temperatures $\left(\mathrm{R}^{2}=0.882\right)$. The results showed the interdependence of slurry, biogas and ambient temperatures. The magnitude of biogas temperatures was slightly different from slurry temperatures because of the differences in the thermal conductivity properties of concrete and brick wall. The biogas was in contact with concrete dome with a thermal conductivity of $0.2 \mathrm{~W} /$ (m.K) while the digester slurry was in contact with the brick wall with a thermal conductivity of $0.8 \mathrm{~W} /$ (m.K). The biogas digester that was not insulated produced biogas of average methane yield of $38 \%$. The second wall for the biogas digester was constructed and sawdust with a thermal conductivity of $0.08 \mathrm{~W} /(\mathrm{m} . \mathrm{K})$ was put in the gap between the inner and outer walls of the biogas digester. The sawdust insulated digester produced average methane yield of 50\% when fed with cow dung. The results showed that insulation of the surface digester improves methane yield. However, insulation does not give $100 \%$ slurry temperature stability even if the digester is built underground.
\end{abstract}

Keywords: Digester, Cow Dung, Temperature, Biogas, Insulation, Methane

\section{Introduction}

Renewable energies play an important role in solving the current and future energy needs of South Africa and in particular biomass. Biomass is very significant because it is a "carbon neutral" fuel [1]. The constant use of fossil fuels as primary energy source has lead to global climate change, environmental degradation, and human health problems [2]. Human beings are now using anaerobic digestion of waste organic materials to generate biogas [3]. Biogas is mixture of gases, predominantly methane and carbon dioxide, produced by anaerobic digestion.

In biogas production temperature of the slurry is an important parameter that affects the rate of biogas production. In nature, methane is formed over a wide of temperature from 0 to $97^{\circ} \mathrm{C}$ [4]. An increase in ambient temperature generally increases the rate of reaction and therefore the rate of biogas production. Temperature is one of the most important factors affecting microbial activity within an anaerobic digester, and methane production is strongly temperature dependent. In general temperature influences three aspects of digester heat requirements; heat loss through digester walls, heat loss through the digester cover and heat required to heat incoming manure to the digester operating temperature [5].

Heat flux through the wall of a digester is given as:

$$
\mathrm{q}_{\text {wall }}=\frac{\left(\mathrm{T}_{0}-\mathrm{T}_{\text {wall }}\right)}{\sum \mathrm{R}_{\text {wall }}}
$$

Where:

$\mathrm{q}_{\text {wall }}=$ heat flux through the wall $\left(\mathrm{W} / \mathrm{m}^{2}\right)$

$\mathrm{T}_{\mathrm{o}}=$ operating temperature of a digester $\left({ }^{\circ} \mathrm{C}\right)$

$\mathrm{T}_{\mathrm{w}}=$ wall surface temperature $\left({ }^{\circ} \mathrm{C}\right)$

$\Sigma \mathrm{R}_{\text {wall }}=$ the total wall resistance $\left(\mathrm{m}^{2} \mathrm{~K} / \mathrm{W}\right)$

Heat loss through the digester is given by; 


$$
\mathrm{Q}_{\mathrm{wall}}=\mathrm{q}_{\mathrm{wall}} \mathrm{A}_{\mathrm{wall}}
$$

Where:

$\mathrm{Q}_{\text {wall }}=$ heat loss through the wall $\left(\mathrm{W} / \mathrm{m}^{2}\right)$

$\mathrm{q}_{\text {wall }}=$ heat flux through the wall

$\mathrm{A}_{\mathrm{wall}}=$ the total area of the walls $\left(\mathrm{m}^{2}\right)$

Fluctuation in digester temperature affects the activity of methane-forming bacteria [6,7]. Temperature influences not only methane-forming bacteria but also volatile acid-forming bacteria. A $10^{\circ} \mathrm{C}$ temperature increase or decrease can stop methane production or methane-forming bacterial activity. Changes in the quantities of organic acids and alcohols that are used directly and indirectly as substrates by methaneforming bacteria affect overall digester performance [8].

Bacteria are classified according to their preferred temperature. Table 1 shows the three main temperature intervals used in anaerobic digestion.

Table 1. Three main temperature intervals used in anaerobic digestion [9]

\begin{tabular}{lll}
\hline Classification & Temperature $\left({ }^{\circ} \mathbf{C}\right)$ & Temperature optimum $\left({ }^{\circ} \mathbf{C}\right)$ \\
\hline Psychrophilic & $0-20$ & 15 \\
Mesophilic & $15-45$ & 35 \\
Thermophilic & $45-75$ & 55 \\
\hline
\end{tabular}

The mesophilic and thermophilic temperatures are well understood, however, current knowledge on psychrophilic biomethanation is scarce [4]. According to [10] anaerobic digestion at psychrophilic temperatures has not been extensively explored as either mesophilic or thermophilic digestion, probably due to little anticipation of development of economically attractive systems using this technology.

The main objective of the paper is to evaluate the performance of biogas digester when fed with cow dung before and after it was insulated with sawdust.

\section{Methodology}

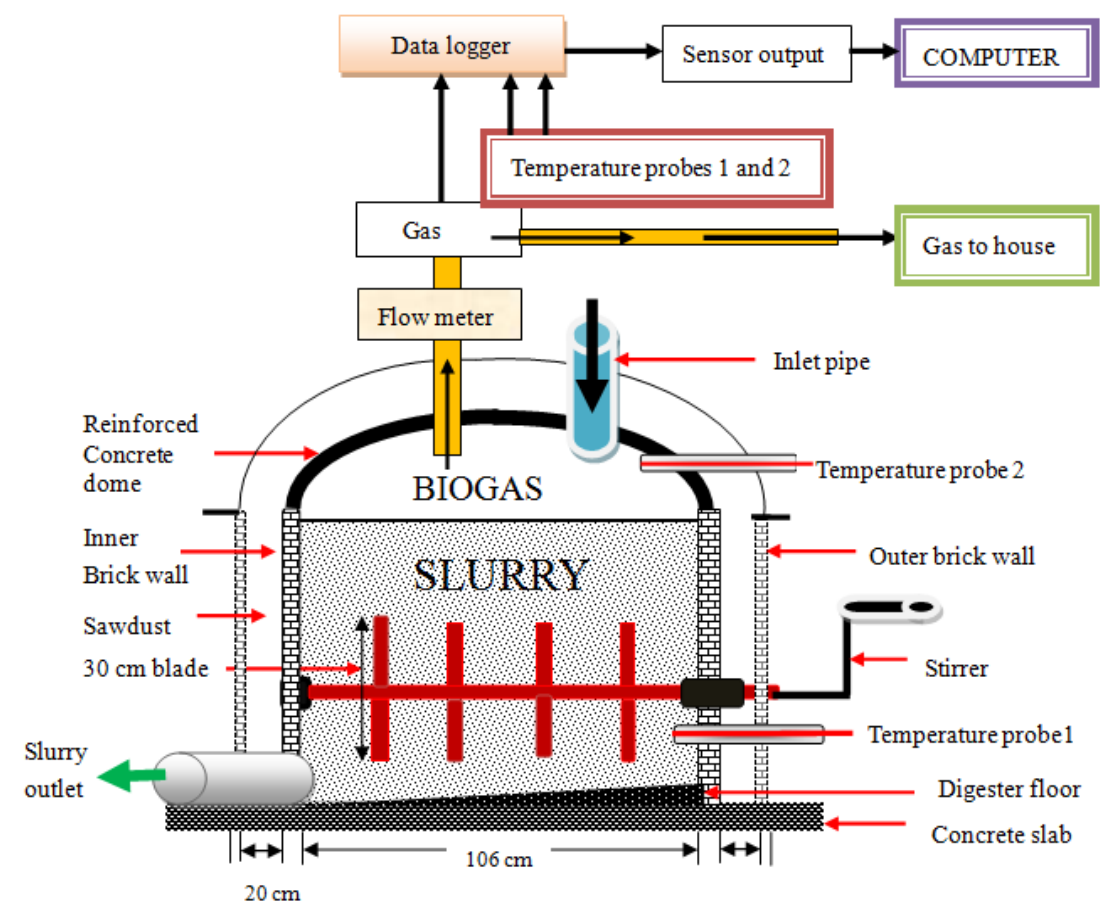

Figure 1. Designed batch biogas digester with various sensors positions.

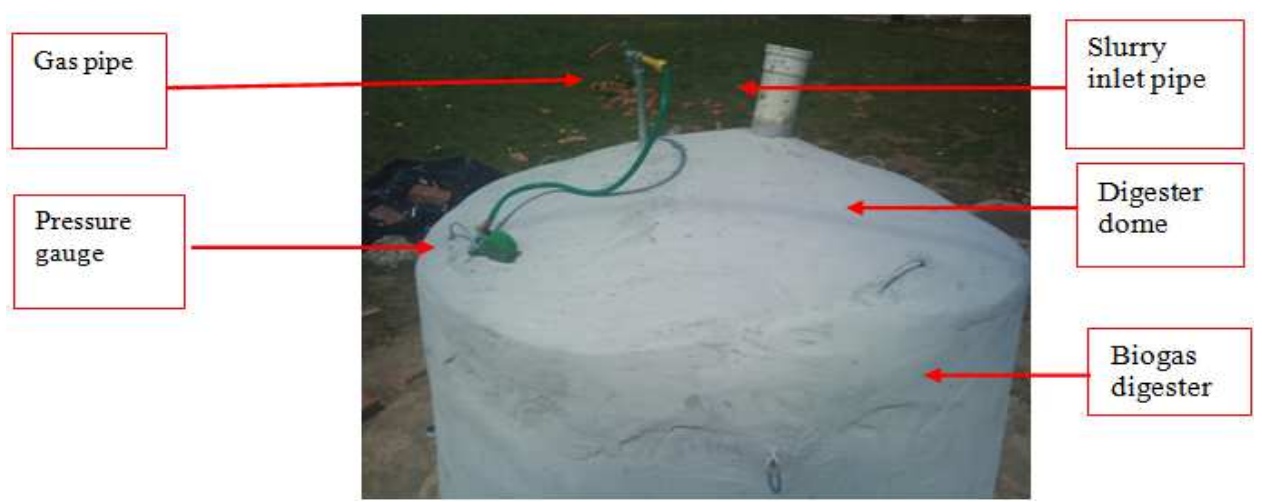

Figure 2. The constructed biogas digester with no insulation. 
Figure 1 shows a designed biogas digester and Figure 2 shows the biogas digester that was built and fed with cow dung before it was insulated. Ambient, biogas and slurry temperatures were measured with type $\mathrm{K}$ thermocouples. The temperature sensors were connected to CR1000 data logger. The data logger was powered by a $12 \mathrm{~V}$ DC rechargeable battery that was connected to a $20 \mathrm{~W}$ photovoltaic module. An analogue pressure gauge was mounted on top of the biogas digester. The experimental set-up is shown in Figure 5.

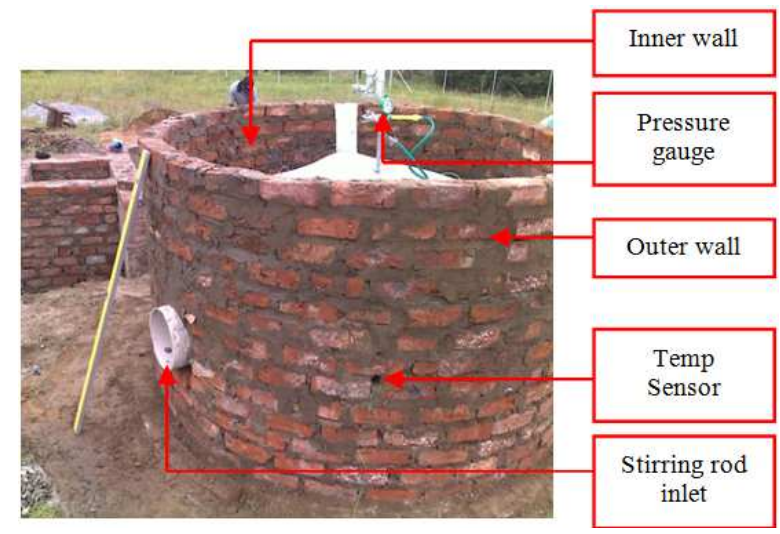

Figure 3. The biogas digester with a second wall.

Figure 3 shows second wall of biogas digester. The second wall was built to ensure maximum insulation of the biogas digester with sawdust. It was single walled. The second wall was slightly higher than the main digester to keep the insulating material within the gap of the two walls.

A plastered second wall for digester insulation is shown in Figure 4. After plastering of the second wall, dry sawdust was put between the two walls as shown in Figure 5. The insulated biogas digester was fed with cow dung. Biogas, slurry and ambient temperatures were measured.

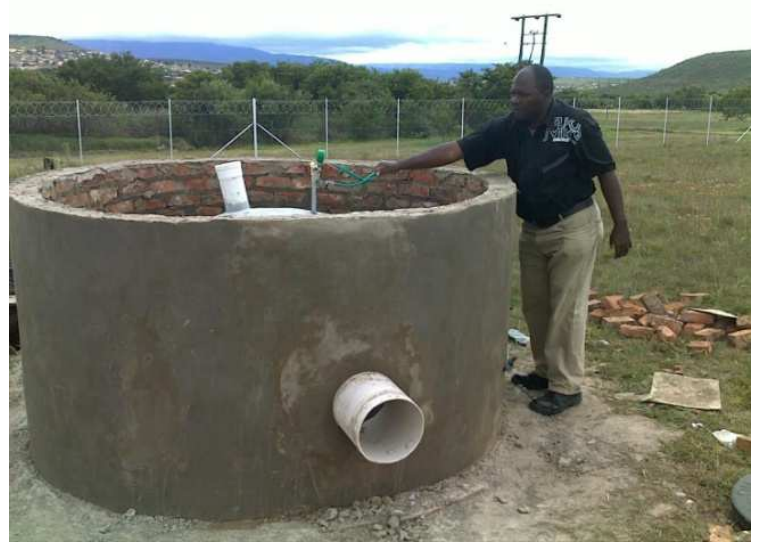

Figure 4. The Plastered second wall digester.

Figure 5 shows the data acquisition system developed. The data acquisition system consisted of a Palladium-Nickel sensor and a Non-Dispersive Infra red sensor.

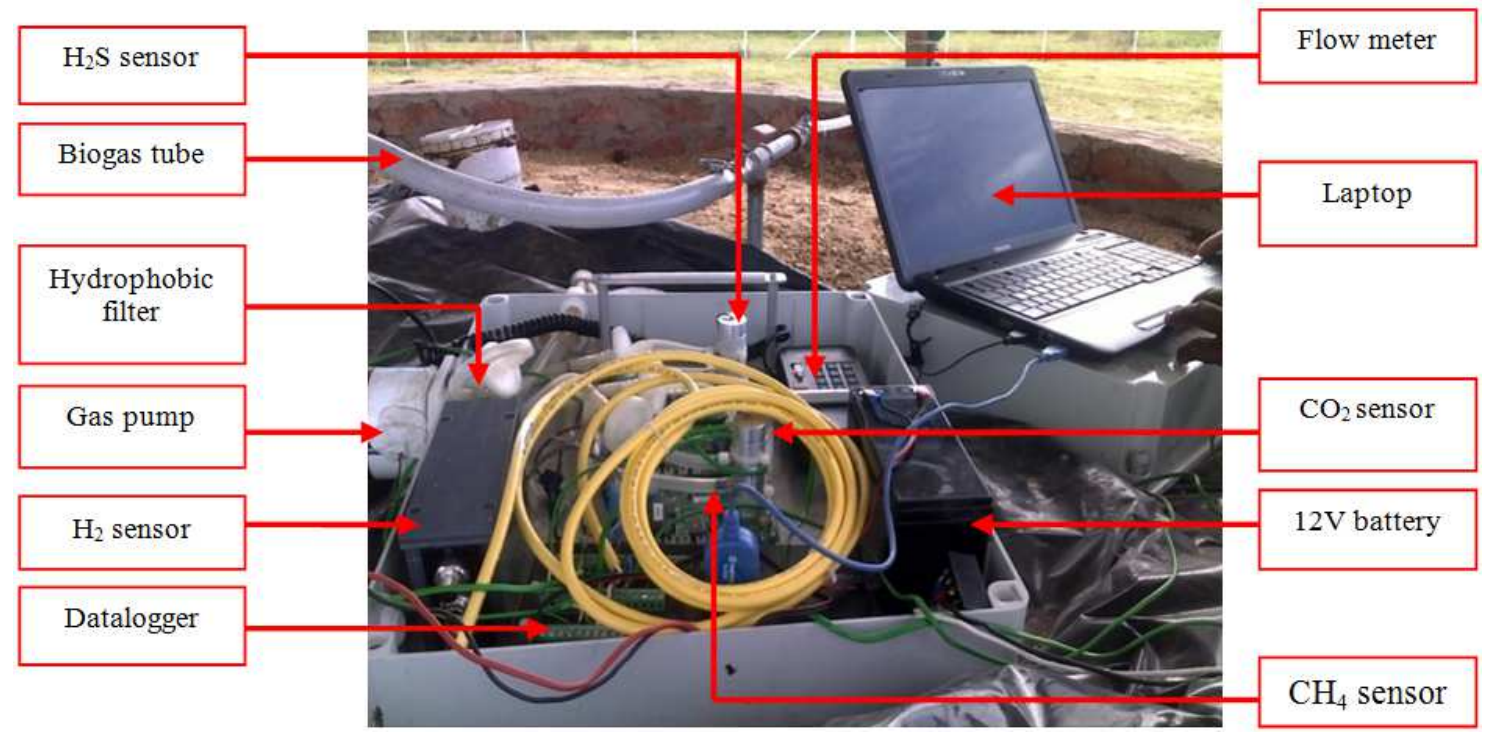

Figure 5. The data acquisition system

\section{Results and Discussions}

\subsection{Temperature Variation and Gas Yield before Insulation of the Biogas Digester}

Figure 6 shows biogas and slurry temperature variations (September) in response to the ambient temperatures before the cow dung fed biogas digester was insulated. The graph shows that there was variation in slurry and biogas temperatures and this motivated the insulation of the batch biogas digester to minimise temperature fluctuations within the digester for maximum biogas production. For a better analysis of the graph, it is divided into three days and each day is also divided into regions as shown in the same figure. 
From Figure 6 it can be seen that biogas and slurry temperature follows the variation of the ambient temperature.

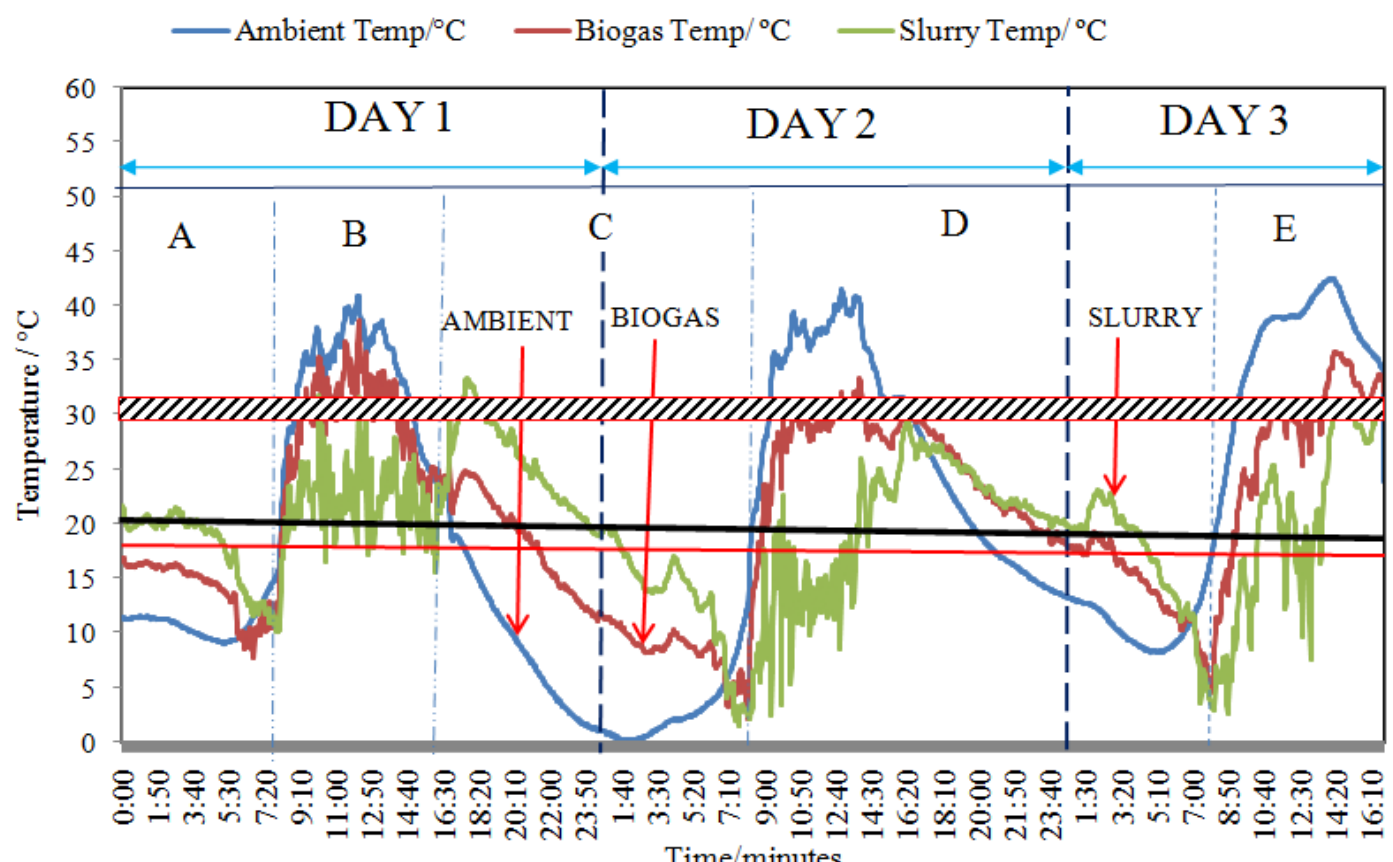

Key

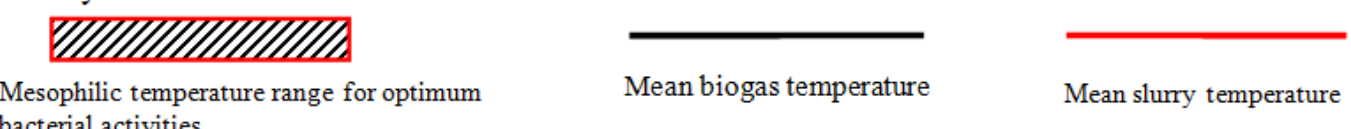

Figure 6. Slurry, ambient and biogas temperatures before insulation (September)

The magnitude of temperature for optimum biogas production without any external heating required was between $\left(29-33^{\circ} \mathrm{C}\right)$ and fell in the mesophilic range. The mesophilic temperature range required for optimum biogas activities is indicated as shown in Figure 6. In addition, Figure 6 shows mean biogas temperature as well as mean slurry temperatures. It was observed that the mean slurry temperature $\left(18^{\circ} \mathrm{C}\right)$ was below the mesophilic temperature range required. Therefore, insulation of the batch biogas digester was required to achieve mesophilic temperature for maximum biogas production. The general behaviour of the temperature profile was almost the same for the whole month and this is why only three days were chosen for the month. Of all the days, during the night, ambient temperature was lower than slurry and biogas temperatures. However, the ambient temperature was higher during the day than slurry and biogas temperatures, with midday experiencing the highest temperatures. For simplicity and analysis purposes, day 1 was divided into regions $\mathrm{A}, \mathrm{B}$ and $\mathrm{C}$; day 2 divided into regions $\mathrm{C}$ and $\mathrm{D}$, and day 3 forms region $\mathrm{E}$.

\subsubsection{Region $A$}

From midnight ambient temperature decreased gradually attaining a minimum value of $10.0^{\circ} \mathrm{C}$ at $7: 56 \mathrm{am}$. Similarly, slurry and biogas temperatures decreased as well from midnight to $9.0^{\circ} \mathrm{C}$ and $8.6^{\circ} \mathrm{C}$ respectively in response to ambient temperature. However, the slurry temperature was higher than ambient temperature because slurry has a higher heat capacity than ambient and biogas. The slurry temperatures were attributed maybe due to heat generating activities of the bacteria in the slurry.

\subsubsection{Region $B$}

The ambient temperature rose sharply from $9.5^{\circ} \mathrm{C}(6: 00$ am) to $40.8^{\circ} \mathrm{C}(12: 10 \mathrm{pm})$ and then dropped drastically from the peak $\left(40.8^{\circ} \mathrm{C}\right.$ ) to $0.3^{\circ} \mathrm{C}$ (region $\mathrm{C}$ ) at $1: 44 \mathrm{am}$. The biogas temperature also rose sharply from $9.3^{\circ} \mathrm{C}$ at $6: 08$ am to $38.2^{\circ} \mathrm{C}$ at $12: 08 \mathrm{pm}$ in response to ambient temperature. There were biogas temperature fluctuations from $30.6^{\circ} \mathrm{C}$ at 9:12 am to $30.4^{\circ} \mathrm{C}$ at $2: 56 \mathrm{pm}$ but the highest temperature reached was $38.2^{\circ} \mathrm{C}$. The slurry temperature rose sharply from $10.3^{\circ} \mathrm{C}$ at $8: 04$ am to $23.4^{\circ} \mathrm{C}$ at $8: 34$ am. The major temperature fluctuations were observed between 9:40 am to 3:02 pm. The highest temperature reached was $31.5^{\circ} \mathrm{C}$ at $12: 08 \mathrm{pm}$. In this region, ambient temperature is higher than slurry due to radiant energy from the sun. The slurry has a higher heat capacity than biogas and ambient. The heat capacity $(\mathrm{Q})=\rho \mathrm{VCT}$, where $\rho=$ density, $\mathrm{V}=$ volume, $\mathrm{C}=$ Specific heat capacity and $\mathrm{T}=$ Temperature change. From the equation, slurry has a higher heat capacity than biogas and ambient because its density is high. During the day biogas temperature is determined by ambient and during the night it is determined by slurry. This is why the biogas temperature is always in between ambient and biogas temperatures.

\subsubsection{Region $C$}

From Figure 6 region $C$ falls within days 1 and 2 . In this region ambient temperature was lower than both biogas and 
slurry temperatures. The biogas temperature increased at first from $22^{\circ} \mathrm{C}(4: 32 \mathrm{pm})$ to $24.7^{\circ} \mathrm{C}(6: 30 \mathrm{pm})$ and then dropped to $9.5^{\circ} \mathrm{C}(2: 34 \mathrm{am})$ in response to slurry temperature. The slurry temperature increased initially from $23.3^{\circ} \mathrm{C}(4: 28 \mathrm{pm})$ to $32.7^{\circ} \mathrm{C}(5: 36 \mathrm{pm})$ and dropped to $15.6^{\circ} \mathrm{C}(2: 18 \mathrm{am})$. The slurry temperature was higher during night because of its high heat capacity as compared to ambient and biogas. The slurry gained heat during the day, and now emitting the heat energy during the night at slow rate due to its high heat capacity than the other media. The high slurry temperatures during the night maybe also be attributed by the bacterial activities within the slurry that generated heat and there was less heat loss to the environment through the digester walls due to the ' 9 inch' brick wall of the batch biogas digester. In addition, the biogas temperature was lower than the slurry temperature because biogas has a low heat capacity than slurry. Furthermore, maybe heat loss from the biogas to the environment through the concrete dome of the digester was higher than heat loss from slurry to the environment through the ' 9 inch' brick wall. This was attributed by the plastered ' 9 inch' brick wall that was thicker $(530 \mathrm{~mm})$ than the concrete digester dome with a thickness of $260 \mathrm{~mm}$, hence less heat loss.

\subsubsection{Region D}

The ambient temperature was higher than biogas and slurry temperatures from 7:02 am to $4: 04 \mathrm{pm}\left(30.5^{\circ} \mathrm{C}\right)$. The highest ambient temperature of $41.5^{\circ} \mathrm{C}$ was recorded at $12: 56$ $\mathrm{pm}$. The major fluctuations in ambient temperature were also observed on biogas temperature. This shows that the digester concrete dome and '9 inch' brick wall did not give an adequate insulation to biogas temperature against ambient temperature. It was further observed that any change in slurry temperature consequently changed biogas temperature. The fluctuation in slurry temperature depicted lack of insulation of the digester. The ambient temperature dropped gradually from the peak and this in turn influenced biogas and slurry temperatures because there was no insulation to exclude ambient temperature. However, the slurry temperature was higher than biogas and slurry temperatures between 7:16 pm to $10: 35$ am due to microbial activities within the slurry. In addition, the slurry temperatures rose from $2.4^{\circ} \mathrm{C}$ at 9:20 am to $20.6^{\circ} \mathrm{C}$ at $9: 54$ am and then dropped and rose again to $27.5^{\circ} \mathrm{C}$. The slurry temperature fluctuated greatly between 7:44 am to $4: 32 \mathrm{pm}$. The slurry temperature was not as high as biogas and ambient temperatures. The high temperature of ambient in this region is a result of radiant energy from the sun. The temperatures of the three media are different because they have different heat capacities. In this case, slurry has a higher heat capacity than biogas and ambient. However, biogas has more heat capacity than ambient.

\subsubsection{Region $E$}

Within this region, ambient temperature increased to a maximum temperature of $41.4^{\circ} \mathrm{C}(1: 44 \mathrm{pm})$ and then dropped. The behaviour of the ambient temperature influenced the biogas and slurry temperatures although biogas temperature was also influenced by slurry temperature. The biogas temperature rose sharply from $5.6^{\circ} \mathrm{C}\left(8: 02\right.$ am) to $35.2^{\circ} \mathrm{C}$ $(2: 20 \mathrm{pm})$ and similarly, slurry temperature rose from a temperature of $3.0^{\circ} \mathrm{C}(8: 02 \mathrm{am})$ to a maximum temperature of $29.5^{\circ} \mathrm{C}(2: 08 \mathrm{pm})$. Within this region, the slurry temperature was lower than biogas temperature. The high temperature of biogas was attributed by heat flow from both the ambient and slurry. Figure 7 shows the variation of slurry temperature in response to ambient temperature.

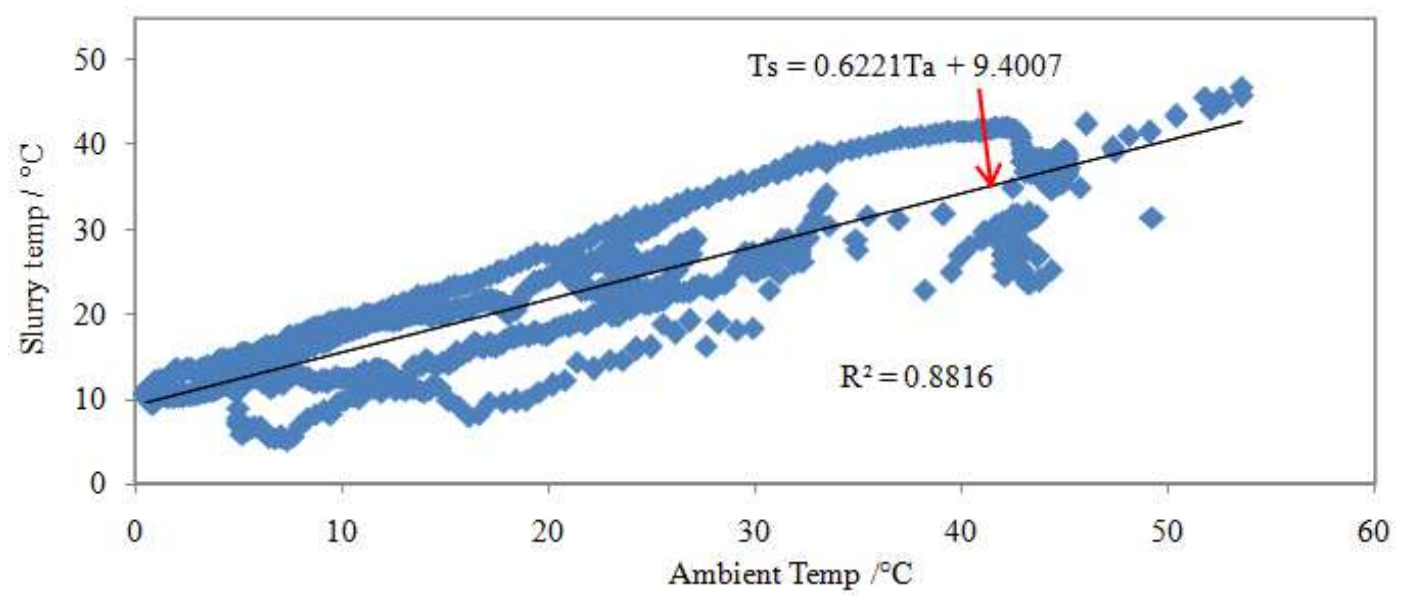

Figure 7. The variation of slurry temperature in response to ambient temperature

From Figure 7 , the coefficient of determination, $\mathrm{R}^{2}$ is 0.8816 . This shows that there is a strong relationship between ambient and slurry temperatures. The relationship between ambient temperature $\left(T_{a}\right)$ and slurry temperature $\left(T_{s}\right)$ from Figure 7 is given as;

$$
\mathrm{T}_{\mathrm{s}}=0.6221 \mathrm{~T}_{\mathrm{a}}+9.4007
$$

Irrespective of the double brick wall structure, the ambient temperatures had a strong impact on slurry temperature. The effects of ambient temperature on the biogas yield call for the need to insulate the batch biogas digester to minimise temperature fluctuations within the digester since big temperature fluctuations reduce the methanogenic activities thus reducing the methane yield.

Figure 8 shows the graph of the biogas yield from cow 
dung before the biogas digester was insulated.

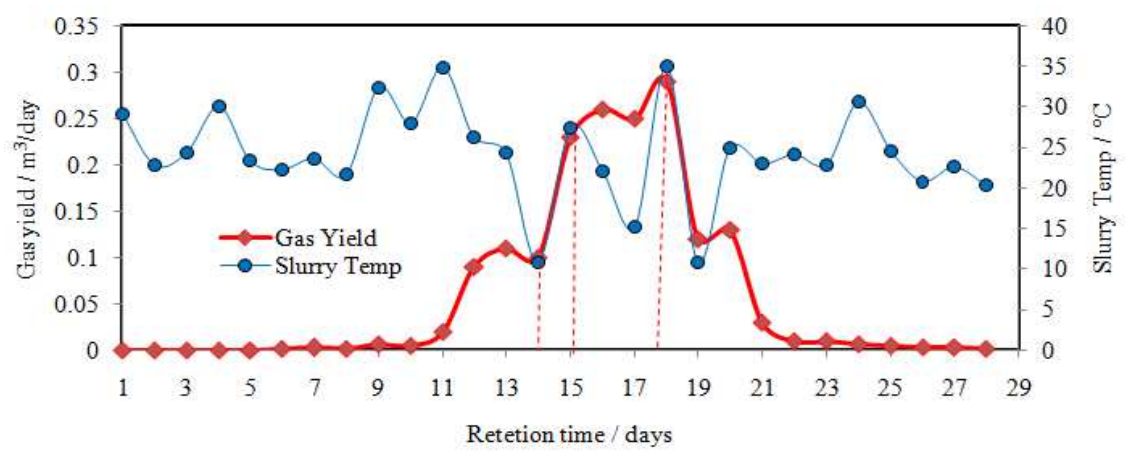

Figure 8. Biogas yield from the cow dung before the digester was insulated

From Figure 8, total biogas yield of $1.68 \mathrm{~m}^{3}$ (after summing up daily biogas production for the whole month) was produced within a retention period of 28 days. The biogas production was noticed on day 9 , and it increased, attaining a maximum gas yield of $0.29 \mathrm{~m}^{3}$ on day 18 . The biogas production rose as from day 10 to day 13 and dropped from day 13 to day 14 . This was attributed by temperature fluctuations that made some of the methanogenic bacteria to stop producing biogas. The ambient temperature dropped from $24^{\circ} \mathrm{C}$ (day 13) to $10^{\circ} \mathrm{C}$ (day 14) as shown on Figure 8 . This inhibition that occurred in the digester resulted in a loss of activity of the methanogenic bacteria and hence low biogas yield.

From Figure 8, the total biogas yield of $1.68 \mathrm{~m}^{3}$ was produced in a retention period of 30 days. The biogas production was noticed on day 10 , increased attaining a maximum gas yield of $0.29 \mathrm{~m}^{3}$ on day 18. The biogas production rose as from day 10 to day 13 and dropped sharply from day 13 to day 14 . This was attributed by temperature fluctuations that made some of the methanogenic bacteria to stop producing biogas. This inhibition that occurred in the digester resulted in a loose of activity of the methanogenic bacteria and hence low biogas yield. Literature had confirmed that a $10^{\circ} \mathrm{C}$ temperature increase or decrease in the digester can stop methane forming bacterial activities [8]. The methanogens later adjusted to the new temperature and biogas production increased rapidly from day 14 to day 16. Furthermore, there was a drop in biogas production from day 16 to day 17 caused by lack of digester insulation resulting in temperature fluctuations. The biogas production suddenly rose from day 17 to the peak (day 18) and then dropped since the food for the methanogens was diminishing (batch process) causing death of some of the methanogens. The biogas production continued to decrease until the biogas yield almost levelled off. However, there was a slight increase in biogas production from day 19 to day 20 .

The biogas production is an indicator how methanogens are affected by ambient temperatures. Many methanogens cease producing biogas as a result of fluctuating digester temperature. Fluctuations in digester temperatures should be less than $1{ }^{\circ} \mathrm{C}$ per day for thermophiles and $2^{\circ} \mathrm{C}$ to $3^{\circ} \mathrm{C}$ per day for mesophiles [8]. Therefore, from the results of the experiments, it was observed that certain group of methane forming bacteria can acclimatize to temperature fluctuations and still produce biogas.

Table 2 shows methane yield from cow dung before the biogas digester was insulated. The biogas produced by an uninsulated biogas digester had a methane content of $38 \%$ and carbon dioxide content of $50 \%$.

Table 2. Biogas yield of cow dung before insulation of the digester

\begin{tabular}{ll}
\hline Gases & Composition (\%) \\
\hline Methane $\left(\mathrm{CH}_{4}\right)$ & 38 \\
Carbon dioxide $\left(\mathrm{CO}_{2}\right)$ & 50 \\
Hydrogen $\left(\mathrm{H}_{2} \mathrm{~S}\right)$ & 0 \\
Hydrogen $\left(\mathrm{H}_{2}\right)$ and other gases & 12 \\
\hline
\end{tabular}

3.2. Temperature Variation and Gas Vield after Insulation

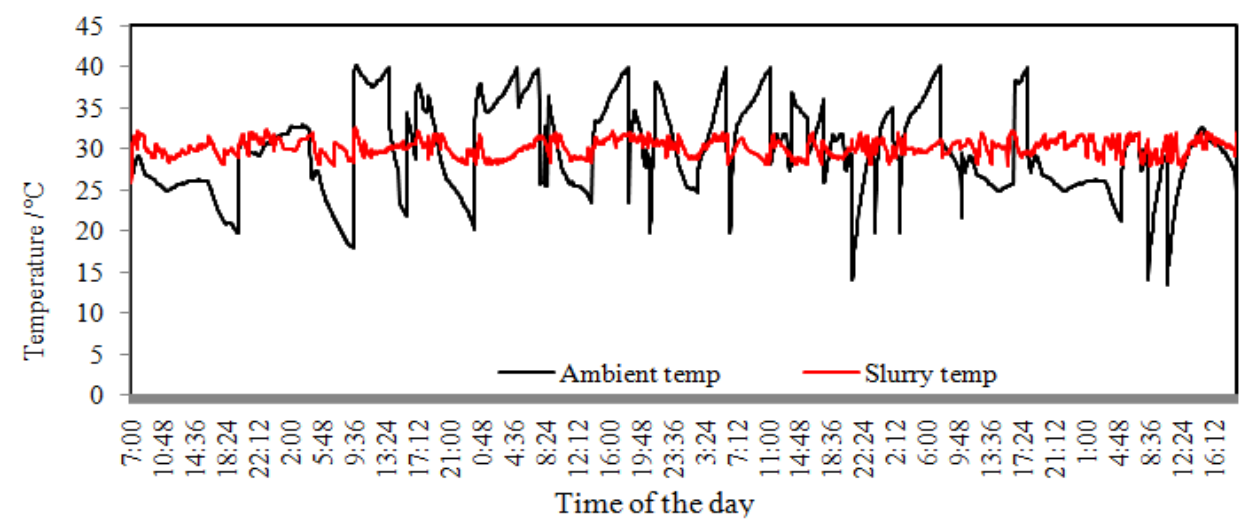

Figure 9. Variation of slurry temperature in response to ambient temperature after insu 
Figure 9 shows the effect of insulation on slurry and ambient temperatures. Ambient temperatures had minor effect on slurry temperatures. Slurry temperatures fluctuated between $28-31{ }^{\circ} \mathrm{C}$ while ambient temperatures fluctuated between $14-52^{\circ} \mathrm{C}$ during the anaerobic digestion process. The average slurry temperature of the biogas digester after insulation was $30^{\circ} \mathrm{C}$. The biogas yield from cow dung after insulation was much higher than biogas yield before insulation. The slurry temperatures are independent of ambient temperatures due to the presence of the insulating material. However, sawdust like any other insulating material does not give $100 \%$ insulation.

Table 3. Main characterization parameters for cow dung

\begin{tabular}{ll}
\hline Parameter & Value \\
\hline Total solids (mg/L) & 168160.48 \\
Volatile solids (mg/L) & 117370.89 \\
Volatile solid /total solid \% & 69.80 \\
Total alkalinity (mg/L) & $2071-2465$ \\
Ammonium-nitrogen (mg/L) & $125-230$ \\
Calorific value (MJ/g) & 25.39 \\
\hline
\end{tabular}

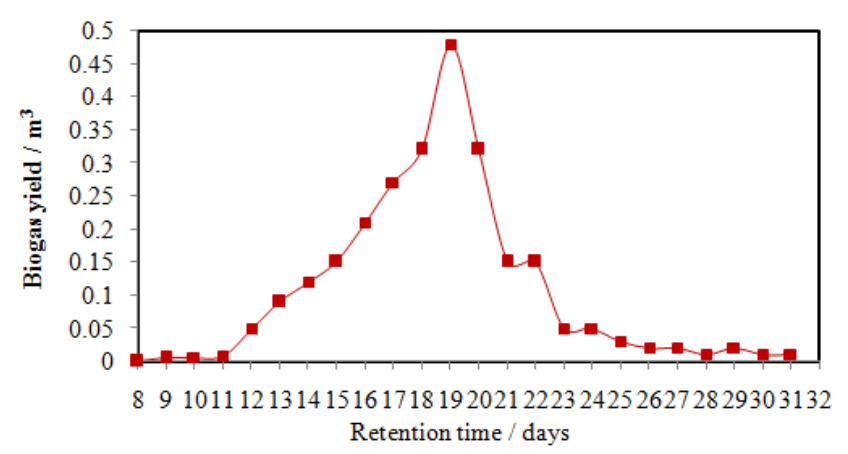

Figure 10. Biogas yield for cow dung

Table 3 shows the main characterization parameters for cow dung. The total alkalinity of 2071-2465 mg/L was adequate to maintain optimal biological activity and stability of the anaerobic digestion system. The ammonia-nitrogen ranged from $125-230 \mathrm{mg} / \mathrm{L}$ in the biogas digester. The values obtained were not high enough to cause any inhibition. High ammonia concentrations can inhibit anaerobic digestion. Ammonia concentrations below $2 \mathrm{~g} / \mathrm{L}$ are beneficial to anaerobic process since nitrogen is an essential nutrient for anaerobic micro-organisms [11].

The daily biogas yield per day of cow dung when the digester was insulated is graphically presented in Figure 10. The experiment was carried out under biogas temperature range of 28 to $32^{\circ} \mathrm{C}$ and for a retention period of 31 days. From Figure 10, it was observed that the biogas production started to increase from day 11 and kept increasing until reaching the peak value of $0.5 \mathrm{~m}^{3}$ on day 19 and then declined to $0.03 \mathrm{~m}^{3}$ on day 25 . The results obtained were indicative of strong microbial activities in the biogas digester. From day 11 to day 18 the gas yield (Y) is approximated by the equation:

$$
\mathrm{Y}=0.052 \mathrm{t}-0.462 \text { for } 11 \leq \mathrm{t} \leq 18
$$

While from day 19 to day 23, the gas yield is approximated by:

$$
\mathrm{Y}=-0.165 \mathrm{t}+3.121 \text { for } 19 \leq \mathrm{t} \leq 23
$$

The rapid biogas production between day 11 and 19 was attributed to readily biodegradable organic matter in the substrate and presence of high content of the methanogens. The total volume of biogas produced was $2.55 \mathrm{~m}^{3}$. The total biogas yield of $70 \%\left(1.71 \mathrm{~m}^{3}\right)$ was attained in the first 19 days before the biogas yield declined. However, the biogas yield from day 19 to day 31 was $30 \%\left(0.54 \mathrm{~m}^{3}\right)$ of the total biogas production. It was observed that after day 23 of the experiment the biogas digester produced less than $0.03 \mathrm{~m}^{3}$ of biogas per day. The methane yield from cow dung after insulation is shown in Table 4.

Table 4 shows the biogas yield for cow dung after the digester was insulated.

Table 4. Biogas composition for cow dung after biogas digester insulation

\begin{tabular}{ll}
\hline Gases & Composition (\%) \\
\hline Methane $\left(\mathrm{CH}_{4}\right)$ & 50 \\
Carbon dioxide $\left(\mathrm{CO}_{2}\right)$ & 40 \\
Hydrogen $\left(\mathrm{H}_{2} \mathrm{~S}\right)$ & 0 \\
Hydrogen $\left(\mathrm{H}_{2}\right)$ and other gases & 10 \\
\hline
\end{tabular}

Insulation of the batch digester was advantageous because it produced a higher biogas of methane content of $50 \%$ as compared to an average methane content of $38 \%$ before it was insulated. Temperature fluctuation within the digester was between $8^{\circ} \mathrm{C}-40^{\circ} \mathrm{C}$ before the digester was insulated. Therefore, from the results of the experiments, it was observed that certain group of methane forming bacteria can acclimatize to temperature fluctuations, hence biogas production.

\section{Conclusion and Recommendations}

Biogas and slurry temperatures of a biogas digester depend completely on ambient temperatures. When the biogas digester is not insulated there is an increase in temperature fluctuations as a result of heat transfer from the environment into the digester through the double wall brick structure of the biogas digester. Biogas production is highly affected by temperature fluctuations. The methane producing microbes are very sensitive to these temperature fluctuations. Insulating the biogas was seen as a way to minimize the fluctuations but not to prevent them completely, even if the biogas digester is built underground. Sawdust has been used as insulating because of its low thermal conductivity of 0.08 $\mathrm{W} /$ (m.K). It has been noted that there was minimum heat loss from slurry to the soil through the digester floor. Temperature fluctuations depend on the quality and quantity of waste used, geometry of the digester, wall and floor thickness of the biogas digester and ambient temperatures of that location. 
It can also be concluded that it is cheaper to build a surface biogas digester than an underground one. The quality and quantity of biogas produced in both digesters is the same as long as the surface digester is well insulated. Cleaning the surface digester is easier than the underground digester.

In designing biogas digesters it necessary to know how thermal gradient can be determined and why this knowledge is important and also the determination of the total heat exchange through a wall made of concrete or bricks should be known so as to come up with the suitable insulating material. However, a biogas designer should determine the best solution within the limitations established by cost and availability of materials.

\section{References}

[1] F. Fantozzi and C. Buratt: Biogas production from different substrates in an experimental Continuously Stirred Tank Reactor anaerobic digester. Bio-resource Technology, Vol. 100 (2009), pp 5783-5789.

[2] I.N. Budiyano, Widiasa, S. Johari. and Sunarso, The kinetic of biogas production rate from cattle manure in batch mode. International Journal of Chemical and Bio-molecular Engineering, Vol. 2 (2010), pp. 39-44.

[3] J. Patil, M.A. Lourdu, , R. Antony and C.C. Gavimath: Study on effect of pre-treatment methods on biomethanation of water hyacinth, International Journal of Advanced Biotechnology and Research, Vol. 2(2011), pp. 143-147.

[4] R.K. Dhaked, P. Singh, and L. Singh, Biomethanation under Psychrophilic conditions, Biotechnology Division, Defence Research and Development Establishment, Gwalior 474002, India (2010).

[5] W. Chen: (Sensitivity Analysis for a Plug-Flow Anaerobic Digester. A Master of Engineering Project, University of Cornell (2007).

[6] D. Fulford: Running a Biogas Programme, (ITDG Publishing, UK. 2001).
[7] B.T. Nijaguna: Biogas Technology (New Age International (P) Limited, Publishers, New Delhi 2002).

[8] M. H. Gerardi: The Microbiology of Anaerobic Digesters, (John Wiley and Sons, New Jersey 2003).

[9] A. Davidsson: Increase of biogas production at waste water treatment plant- Addition of urban organic waste and pretreatment of sludge, Water and Environmental Engineering, Department of Chemical Engineering, Lund University, Sweden (2007).

[10] U. Balasubramaniyam, L.S. Zisengwe, N. Meriggi, and E. Buysman: Biogas Production in Climates with long cold Winter, Wageningen: Wageningen University (2008).

[11] T. Liu and S. Sung: Ammonia inhibition on thermophilic aceticlastic methanogens Water Science \& Technology Vol. 45, (2002), pp .113-120.

[12] G. Eason, B. Noble, and I. N. Sneddon, "On certain integrals of Lipschitz-Hankel type involving products of Bessel functions," Phil. Trans. Roy. Soc. London, vol. A247, pp. 529-551, April 1955. (references)

[13] J. Clerk Maxwell, A Treatise on Electricity and Magnetism, 3rd ed., vol. 2. Oxford: Clarendon, 1892, pp.68-73.

[14] I. S. Jacobs and C. P. Bean, "Fine particles, thin films and exchange anisotropy," in Magnetism, vol. III, G. T. Rado and H. Suhl, Eds. New York: Academic, 1963, pp. 271-350.

[15] K. Elissa, "Title of paper if known," unpublished.

[16] R. Nicole, "Title of paper with only first word capitalized," J. Name Stand. Abbrev., in press.

[17] Y. Yorozu, M. Hirano, K. Oka, and Y. Tagawa, "Electron spectroscopy studies on magneto-optical media and plastic substrate interface," IEEE Transl. J. Magn. Japan, vol. 2, pp. 740-741, August 1987 [Digests 9th Annual Conf. Magnetics Japan, p. 301, 1982].

[18] M. Young, The Technical Writer's Handbook. Mill Valley, CA: University Science, 198. 